九州大学学術情報リポジトリ

Kyushu University Institutional Repository

\title{
Texturization of Whole Soybean in a Twin-Screw Extruder
}

Hayakawa, Isao

Laboratory of Food Technology, Faculty of Agriculture, Kyushu University

Hayashi, Nobuyuki

Laboratory of Food Technology, Faculty of Agriculture, Kyushu University

Urushima, Takashi

Laboratory of Food Technology, Faculty of Agriculture, Kyushu University

Kajiwara, Yoshinori

Laboratory of Food Technology, Faculty of Agriculture, Kyushu University

他

https://doi.org/10.5109/23931

出版情報：九州大学大学院農学研究院紀要. 33 (3/4)，pp.213-220，1989-03. Kyushu University バージョン：

権利関係: 


\title{
Texturization of Whole Soybean in a Twin-Screw Extruder
}

\author{
Isao Hayakawa, Nobuyuki Hayashi, Takashi Urushima \\ Yoshinori Kajiwara and Yusaku Fujio
}

Laboratory of Food Technology, Faculty of Agriculture Kyushu University 46-09, Fukuoka 812, Japan.

(Received September 22, 1988)

\begin{abstract}
Good meat-like extrudates were manufactured from full fat soybean flour using a twin-screw extruder. From the results of FT-IR analysis, no noteworthy new chemical bonds were present in the formation of the matrix, and deamidation was observed. From the results of flow double refraction analysis, viscosity measurement, FT-IR analysis and sodium dodecyle sulfate polyacrylamide gel electrophoresis, the S-S bond did not play an important role on the formation of the matrix, and a large number of molecules in the products had a reduction in molecular weight and shifted to chain structure. It was considered that the matrix was formed by entanglements of linearized proteins and ploysaccharides in soybeans by shearing into the materials molten by high temperature and high pressure in the presence of water.
\end{abstract}

\section{INTRODUCTION}

Many kinds of foods such as various snacks, texturized products from vegetable proteins, and brewing materials for beer and alcohol fermentation are processed in a single-screw (Katoh and Hayakawa et al., 1985) or a twin-screw extruder (Association of Extrusion Cooking Technology Development, 1987, Gomez et al., 1984, Phillips, et al., 1984, Noguchi et al., 1984, Davidoson et al., 1984). However, a method for the direct manufacture of products possessed a meat-like texture from full fat soybean flour has not been established. In this study, a method for continuous manufacture of products with a texture similar to that of meat using a twin-screw extruder is described. This study was of the mechanism of texture formation from full fat soybean flour through extrusion cooking. The properties of the extrudates were examined under a scanning electron microscope. Also the molecular configuration of the raw material and extrudates were studied with a flow double refractometer (flow birefringence meter) and a viscometer, and the distribution of molecular weight was measured by electrophoresis. Fourier-tranform-IR (FT-IR) analysis of the raw material and the product was also done to find whether newly formed chemical bonds contributed to formation of a matrix in the extrudates.

\section{MATERIALS AND METHODS}

\section{Materials}

Dehulled soybeans grown in the northern part of the U. S. Midwest were used. General analysis of sample showed $37.8 \%$ protein (by Kjeldahl method, nitrogen X 5.71), $25.5 \%$ lipids 8by extraction with equal volumes of chloroform and methanol), $27.7 \%$ 
sugars (subtraction method), $4.3 \%$ ash, and $10.7 \%$ moisture (by drying at $105^{\circ} \mathrm{C}$ )

\section{Extrusion cooking}

A twin-screw extruder (model KEI-45, Kowa Kogyo, Co. Ltd.) with length/diameter of 12 was used for present study with water addition. High shearing screw configurations were used in this experiment. The feed rate of the sample was 15-25 $\mathrm{kg} / \mathrm{hr}$, and water was added to maintain the $35-50 \%$ moisture in the products. The temperature of the material inside the barrel during extrusion was measured using a heat-sensitive paint mixed with the sample. The color changes of the mixture were observed after the extruder was stopped.

\section{Solubility}

The solubility of the raw material and the product was expressed by nitrogen soluble index according to the method of Siao et al. (1974, 1975).

\section{Cryo-scanning electron microscopy (Cryo-SEM)}

For observation of products, a SEM (model JSM-T330, JEOL Co. Ltd.) was used. Samples were frozen in liquid nitrogen and observed at $-40^{\circ} \mathrm{C}$ according to the criteria of SEM (Kanto Branch of Japanese Electron Microscope Society, 1985 ; Samejima et al., 1986 ; Hitachi, 1979a, 1979b, 1985).

\section{Infrared analysis}

The fourier-transform infrared analysis (FT-IR) for the full fat soybean flour and the products was taken on a wide-range Marcury-Cadmium-Telluride detector (model JIR-3500, JEOL Co. Ltd.) (Silverstein et al., 1964)

\section{Measurement of flow double refraction}

The Flow double refraction (flow birefringence) for the 5\% solutions of the raw material and extrudates was measured at room temperature $\left(23^{\circ} \mathrm{C}\right)$ by a flow double refraction apparatus (Mizojiri Kogyo Co. Ltd.) under the following conditions ; light path : $30 \mathrm{~mm}$, rotation speed : $60 \mathrm{rpm}$ (Ishino et al., 1986. Nakagaki, 1968).

\section{M easurement of viscosity}

The viscosity of the $5 \%$ protein solution was measured at $30^{\circ} \mathrm{C}$ by Ostwald viscometer.

\section{E lectrophoresis}

Sodium dodecyle sulfate-polyacrylamide gel electrophoresis (SDS-PAGE) (Weber and Osborn 1969 ; Saio et al., 1975) was carried out on a 12\% polyacrylamide gel in presence of $2 \%$ SDS according to the method of Weber and Osborn (1968). A sample solution of the raw material or the product containing $25 \mu \mathrm{g}$ of protein was put on the gel, and a current of $20 \mathrm{~mA}$ was applied. The buffer contained 2\% SDS in absence or presence of a $2 \%$ 2-mercaptoethanol stained by Coomassie Brilliant Blue R-250. The density of the stained bands corresponding to different molecular weights was measured by a densitometer (DMU-33C, Advantec Co. Ltd.) at $640 \mathrm{~nm}$. 


\section{RESULTS}

\section{Solubility and temperature of specimens with various screw positions}

Since the protein solubility was affected strongly by thermal modification, the solubility changed with the temperature distribution along the screws were investigated. Changes in solubility of specimens at different locations along the longitudinal screw shaft in the barrel are shown in Fig. 1. The protein in the full fat soybean flour became insoluble i. e. nitrogen solubility index (NSI) decreased when the sample entered the heating region in the barrel. The total heat generation is quite huge in this region, because heat transfer from the barrel heater is quite huge under high pressure and frictional heat generation among the flour particles is also very big under high pressure heat. One friction is between the inside surface of barrel and the material, the other is between the screw-surface and the material. Thus, since the screw configuration affected the frictional heat generation, protein solubility changed at the different locations along the screw. The full fat soybean flour bacame impossible to resolve. When the soybeans were heated enough in the high temperature zone, the

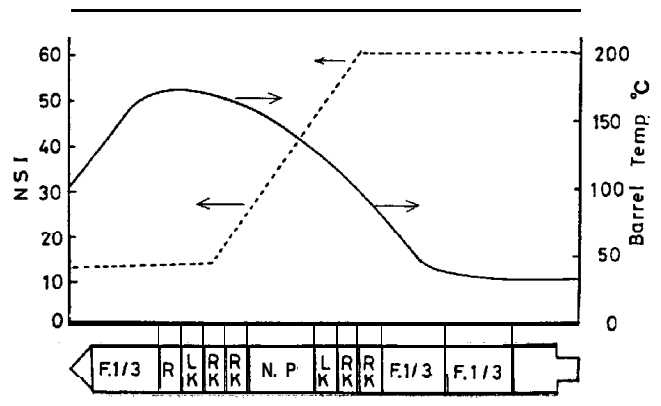

Fig. 1. Relationship between screw configrations and sample temperature and nitrogen solubility index (NSI) of specimens.

NP : paddle screw (normal direction), F : normal pitch forward screw, Rk : kneading screw (turn to the right), $1 / 3 \mathrm{~F}: 1 / 3$ pitch forward screw, Lk : kneading screw (turn to the left), $2 / 3 \mathrm{~F}: 2 / 3$ pitch forward screw

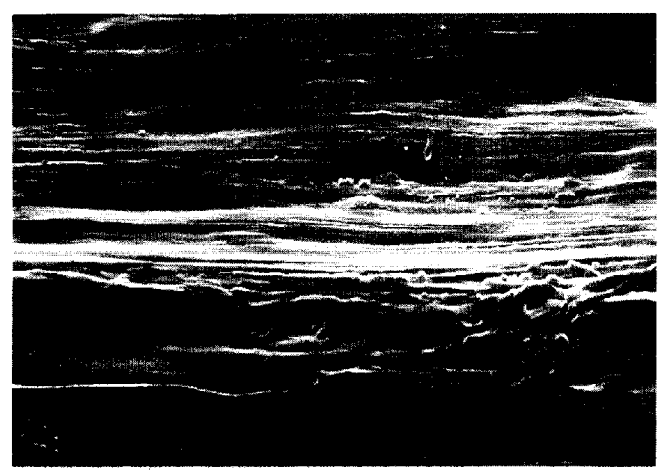

Fig. 2. A scanning electron micrograph of full fat soybean extrudates with meat-like texture. Magnification x 3,000. 
materials were taxturized after melting.

\section{SEM observation for extrudates}

The good tissue texturized from the full fat soybean flour had been oriented to uniaxial. When such products were chewed from the tissue of the fibrous structure, the texture was similar to that of meat. The tissue of extrudates prepared from soybeans was observed under a scanning electron microscope. A longitudinal cross section of the product which possessed a meat-like texture was shown in Fig. 2. The constitutional structure of the material was completely destroyed and oriented as the fiber during the extrusion. The unclear area in the photograph showed a thin layer of oil on the top. To clarify the textural characteristics in more detail, cryogenic observation was applied to an electron microscope. A cross-section of fibrous protein which possessed a meat-like texture was presented as shown in Fig. 3. The tissues in the extrudate were covered with a thin porous membrane emulsified with oils and water. The results suggested that the inside components under the membrane was consisted with oils, proteins, sugars and water. An electron microscopic photograph of an inferior tissue product was shown in Fig. 4. These are large gaps around the oil-based membrane which probably promoted the textural compactness.

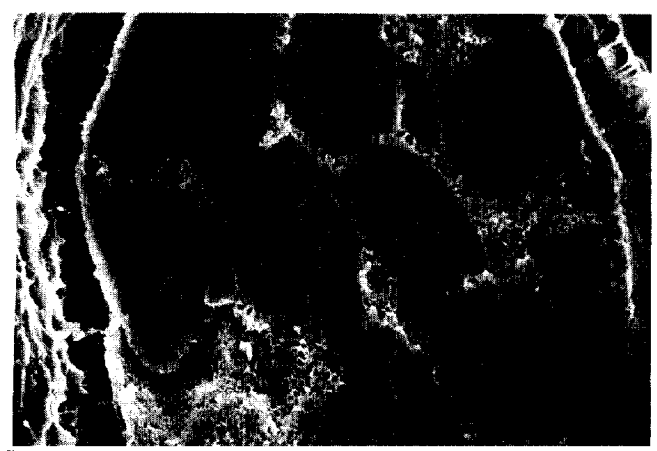

Fig. 3. A scanning electron micrograph of full fat soybean extrudates with good texture under cryogenic obsevation. Magnification x 3,000.

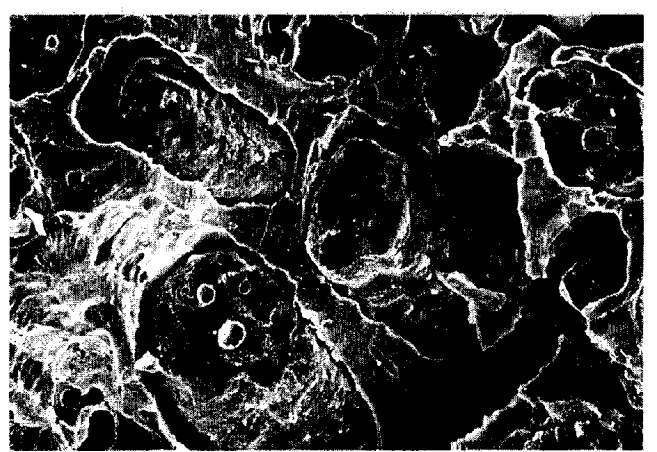

Fig. 4. A scanning electron micrograph of full fat soybean extrudates with inferior texture under cryogenic obsevation. Magnification x 3,000. 


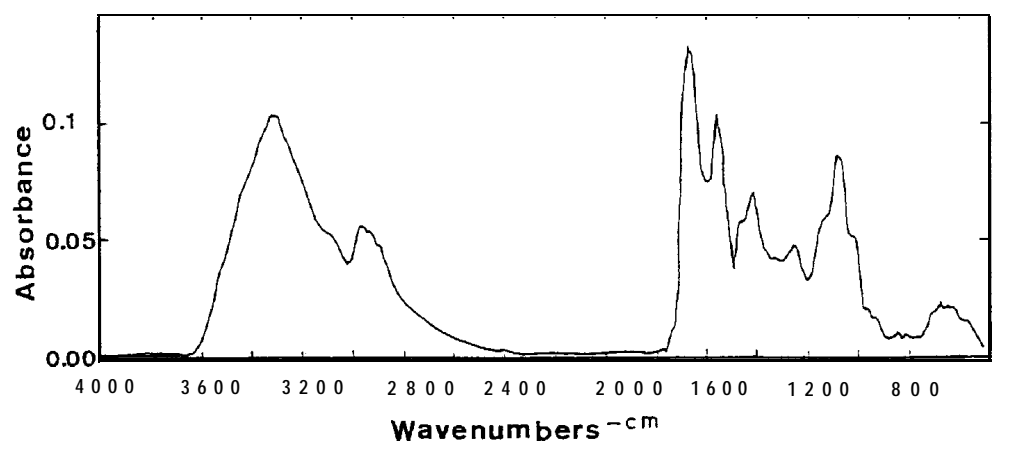

Fig. 5. The subtraction spectrum deducted the FT-IR spectrum of products from that of raw material. Absorbance of carbonyl at $1750^{-\mathrm{cm}}$ was used as a standard mark on the computer calcuration.

\section{FT-IR analysis of full fat soybean flour and product}

We have an idea that new chemical bonds might participate in the formation of texturized structure, when the full fat soybean flour was texturized by the twin-screw extruder, therefore, a subtraction spectrum of FT-IR which is deducted from the spectrum of soybeans to that of extrudates was investigated (Fig. 5). In this experiment, the soybean was used as a specimen, and the extrudate was used as a reference specimen. The absorption of carbonyl at $1750^{-\mathrm{cm}}$ was used as a standard in making a subtraction spectrum from a spectrum of the soybean to that of the product. From the results of the FT-IR analysis, any absorption of new chemical bond was not found in the extrudate. Because the IR absorption was slightly reduced in any wave-length regions. In particular, the absorption showed a high reduction ratio between the wave-length of $3100-3600^{-\mathrm{cm}}$. The decreased absorption in this region mainly reflected the decreasing in primary amides, secondary amides, and $\mathrm{C}-\mathrm{H}$ in the extrudate. The results indicated that new chemical bonds were not involved the formation of a matrix. There was a problem in simple comparison with the other absorption region without same standards, but the decrease of absorption in the vicinity at $2500^{-\mathrm{cm}}$ suggested the cleavage of S-S bonds in the extrudates comparison to that of the raw soybean protein.

\section{Flow double refraction and viscosity}

With intensive shearing action, the tissues of proteins, sugars, or both of them in the soybean were destroyed, and constitutional components of original soybean are re-oriented in uniaxial direction during the extrusion. The flow double refractions of the soybeans and the extrudates solutions (each 5\% solution) were measured to find out some informations in their protein molecular forms (Table 1). The solubility of the soybean and that of extrudates were low in phosphate buffer solution, and the extinction angles were 0.06 and 0 , respectively. The protein molecules of each specimen were seemed to be fold in the phosphate buffer. The double refraction in $8 \mathrm{M}$ urea solution was 0.51 for the soybean and 0.46 for the extrudates. However, the viscosity of the soybeans was slightly larger than that of the extrudates (Table 2). The extinction angles of the soybean were 0.6 or less in all solutions, but those of the extrudates 
Table 1. Flow double refraction full fat soybean and extrudates in various solutions.

\begin{tabular}{lcccc}
\hline \multicolumn{1}{c}{ Specimen } & Phosphate Buffer & $8 \mathrm{M}$ Urea & $2 \%$ SDS $+8 \mathrm{M}$ Urea & 8M Urea+O.Ol 2-ME \\
\hline Soybeans & 0.06 & 0.51 & 0.6 & 0.58 \\
\hline Extrudates & 0.00 & 0.46 & 1.27 & 1.77 \\
\hline
\end{tabular}

*Sample concentration in each solution was about $5 \%$.

Table 2. Viscosities $\left(\eta-\eta_{0}\right)$ of full fat soybean and extrudates in various solutions.

\begin{tabular}{lcccc}
\hline Specimen & Phosphate Buffer & $8 \mathrm{M}$ Urea & $2 \%$ SDS $+8 \mathrm{M}$ Urea & 8M Urea +0.01 1-ME \\
\hline Soybeans & 0.10 & 0.62 & 0.60 & 0.69 \\
\hline Exctrudates & 0.05 & 0.43 & 0.71 & 0.81 \\
\hline
\end{tabular}

$\eta$ : Relative viscosity (cp) of specimen dissolved in each solution.

$\eta_{0}$ : Relative viscosity (cp) of each solution.

*Sample concentration in each solution was about $5 \%$.

increased with the addition of $2 \%$ SDS or $0.01 \mathrm{M} 2$-mercaptoethanol to the $8 \mathrm{M}$ urea solution. These results suggested that the three-dimensional structure of the protein in the extrudates were destroyed completely because of the cleavage of S-S bonds, and became linear structure from fold state of proteins in the $8 \mathrm{M}$ urea solution in presence of the $0.01 \mathrm{M} 2$-mercaptoethanol.

SDS-PAGE of soybeans and extrudates

Results of SDS-PAGE of soybeans and extrudates indicated the mean molecular

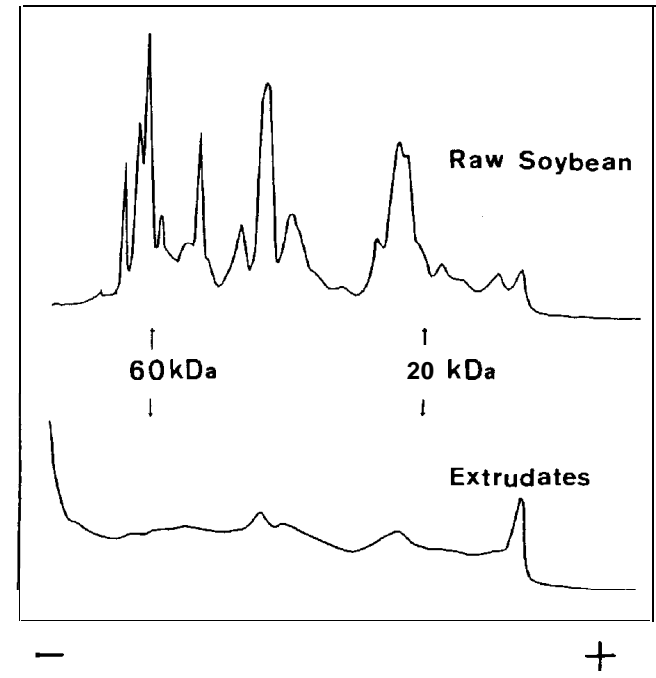

Fig. 6. Denstogrum of raw materials and extrudate. The SDS-polyacrylamide gel electrophoreisis was done by the method of Weber and Osbom, "with $12 \%$ acrylamide gel concentration and $25 \mu \mathrm{g}$ of protein put on each gel. Current was $20 \mathrm{~mA}$. 
weight of all components. The distribution of molecular weight with and without 2mercaptoethanol on SDS-PAGE was almost same (Fig. 6). Especially, the mean molecular weight of protein of extrudates was less than that of the original soybeans.

\section{DISCUSSION}

The products which possess similar texture to that of livestock meat and excellent organoleptic properties has been manufactured successfully from the full fat soybean flour by the twin-screw extruder. For the purpose of clarifying the mechanism of this texturization, present investigations were conducted on the difference between the protein of the raw material and that of extrudates by the twin-screw extruder. The protein molecules of extrudates had been smaller size and more linearized structure as compared with those of the raw material considering the results of the flow double refraction, the viscosity and SDS-PAGE. From the results of FT-IR, it is also considered that deamidation of protein and hydrolysis of hemicellulose in soybean are increased during extrusion. The generation of the special chemical bond participated in the formation of a matrix is hardly considered. Saio et al. $(1974,1975)$ investigated the modification of heat-induced soybean protein in details and reported that soybean protein generated deamidation by heating at $170^{\circ} \mathrm{C}$ for $5 \mathrm{~min}$. Our experimentations followed this result. Further, interchange reactions between $\mathrm{SH}$ and $\mathrm{S}-\mathrm{S}$ were reduced to in a minimal degree in the products. The flow double refraction value of the extrudates is larger than that of the raw soybean. When 2-mercaptoethanol is added to the solution of both of them, the viscosity of the raw soybean solution decreased abruptly but that of the solution of the extrudates increased suddenly. This phenomenon reflects the fundamental difference between the molecular structures of both specimens i. e., some kinds of protein in the raw soybean form large molecular structures where in subunits are linked by the S-S bond, while the three dimensional structure of the protein in extrudates is already destroyed to linearization or chain structure and, some kinds of linearized protein molecules in the extrudates have a loop in their structure. It is suggested that this loop is cloven by the addition of 2mercaptoethanol to indicate a linear chain structure and the increase in flow double refraction value and that in viscosity are shown. And also, the mobility of extrudates on the SDS-PAGE was very high when the gel was prepared with less than $10 \%$ concentrates. Because the decreasing of molecular weight of extrudates has been done by high shear rate and high pressure under the high temperature in the barrel of extruder.

\section{REFERENCES}

Association of Extrusion Cooking Technology Development 1987 "Extrusion Cooking", Korin. Tokyo

Davidson, J. V., D. Paton., L. L. Diosady. and L. J., Rubin 1984 A model for mechanical degradation of wheat starch in single-screw extruder. J. Food Sci., $49: 1154-1157$

Gomez, H. M. and J. M. Aguilera 1984 A physicochemical model for extrusion of corn starch. $J$. Food Sci., $49: 40-46$

Hitachi 1979a Hitachi Technical Data SEM No. 20

Hitachi 1979b Hitachi Technical Data SEM No. 21

Hitachi 1985 Hitachi Technical Data SEM No. 23 
Isono, K., K. Kobinata., H. Oikawa, H. Kusakabe, M. Uramoto, K. Ko, T, Misato,W. S. Tai., C. Y. Ni., and Y. C. Shen 1986 New antibiotic, albopeptins A and B. Agric. Biol. Chem 50 : 2163-2165

Kanto Branch of Japanese Electron Microscope Society 1985 "Foundation and Application of Scanning Electron microscope", Kyoritsu Shuppan, Tokyo, p. 253-263

Katoh, T, N. Hayashi, S. Kawasaki and I. Hayakawa 1986 The influence of temperature, pressure and shearing action on the gelatinization of starch, Nippon Shokuhin Kogyo Gakkuishi, 33 : 8-13

Mizushima, S. and S. Akabori 1964 "Protein Chemistry Vol. II", Kyoritsu Shuppan, Tokyo, p. 395 $-400$

Nakagaki, M. 1963 "Surface State and Colloid", Tokyo Chemical Coterie, Tokyo, p. 191-227

Noguchi, A. and J. C. Cheftel 1983 Extrusion-cooking of protein-enriched cookies. Nippon Shokuhin Kogyo Gakkaishi. 30: 114-124

Phillips, D. R., M. S. Chhinnan and M. B. Kennedy 1984 Effect of feed moisture and barrel temperature on physical properties of extruded cowpea meal. J. Food Sci.49: 916-921

Saio, K., I. Sato and T. Watanabe 1974 Food use of soybean 7S and 11S protein : High temperature expansion characteristics of gels. J. Food Sic. 39 : 777-780

Saio, K, M. Terasaki, and T. Watanabe 1975 Food use of soybean $7 \mathrm{~S}$ and 11S protein: Heat denaturation of soybean proteins at high temperature J. Food Sci $40: 537-540$

Samejima K., Y. Oka, K. Yamamoto, A. Asghar and T. Yasui 1986 Effects of temperature, actin-myosin ration, $\mathrm{pH}$ and salt protein concentrations on heat induced gelling of cariac myosin and reconstituted actomyosin. Agric. Biol. Chem. 50: 2101-2110

Silverstein M. R. and G. C. Bassler 1964 "Identification Method by Spectrum of Organic Compound" translated by Araki S, and Mashiko Y. Tokyo Chemical Coteritie, Tokyo, p. 49-73

Weber K, and M. Osborn 1969 The Reliability of molecular weight determinations by dodecyl sulfate-polyacrylamide gel electrophoresis. J. Biol. Chem. 244: 4406-4412 